\title{
Metalliferous Mine Dust: Human Health Impacts and the Potential Determinants of Disease in Mining Communities
}

\author{
Jane A. Entwistle ${ }^{1}$ (D) Andrew S. Hursthouse ${ }^{2}$ Paula A. Marinho Reis ${ }^{3,4} \cdot$ Alex G. Stewart $^{5,6}$
}

Published online: 21 May 2019

(C) The Author(s) 2019

\begin{abstract}
Purpose of Review Many factors influence the health impact of exposure to metalliferous mine dusts and whilst the underpinning toxicology is pivotal, it is not the only driver of health outcomes following exposure. The purpose of this review is twofold: (i) to highlight recent advances in our understanding of the hazard posed by metalliferous mine dust and (ii) to broaden an often narrowly framed health risk perspective to consider the wider aetiology of the potential determinants of disease.

Recent Findings The hazard posed by metalliferous dusts depends not only on their abundance and particle size but other properties such as chemical composition, solubility, shape, and surface area, which all play a role in the associated health effects. A better understanding of the mechanisms that lead to toxicity, such as recent advances in our understanding of the role played by reactive oxygen species (ROS), can help in the development of improved in vitro models to support risk assessments, whilst biomonitoring studies have the potential to guide risk management decisions for mining communities.

Summary Environmental exposures are complex; complex geochemically and complex geographically. Research linking the environment to human health is starting to mature, highlighting the subtlety of multiple exposures, mixtures of substances, and the cumulative legacy effects of life in disrupted and stressed environments. We are evolving more refined biomarkers to identify these responses, which enhances our appreciation of the burden of effects on society and also directs us to more sophisticated risk assessment approaches to adequately address evolving regulatory and societal needs.
\end{abstract}

Keywords Exposome $\cdot$ Bioaccessibility $\cdot$ Biomonitoring $\cdot$ Mining legacy $\cdot$ Risk assessment

This article is part of the Topical Collection on Human Health Effects of Environmental Pollution

Jane A. Entwistle

jane.entwistle@northumbria.ac.uk

Andrew S. Hursthouse

andrew.hursthouse@uws.ac.uk

Paula A. Marinho Reis

pmarinho@dct.uminho.pt

Alex G. Stewart

dragonsteeth@doctors.org.uk

1 Department of Geography and Environmental Sciences, Northumbria University, Ellison Building, Newcastle Upon Tyne NE1 8ST, UK
2 School of Computing, Engineering \& Physical Sciences, University of the West of Scotland, Paisley PA1 2BE, UK

3 Departamento de Ciências da Terra, Escola de Ciências, Universidade do Minho, Campus de Gualtar, 4710-057 Braga, Portugal

4 GeoBioTec, Departamento de Geociências, Universidade de Aveiro, Campus de Santiago, 3810-1934RJ Aveiro, Portugal

5 College of Life and Environmental Science, University of Exeter, Exeter EX4 4RJ, UK

6 Public Health Institute, Faculty of Education, Health and Community, Liverpool John Moores University, Liverpool L2 2QP, UK 


\section{Introduction}

'We have been mortgaging the health of future generations to realise economic and development gains in the present' [103].

Environmental pollution contributed to an estimated 9 million deaths and significant economic losses across the world in 2015 [62]. Indeed, The Lancet Commission on pollution and health identifies pollution as the largest environmental cause of disease and premature death [62]. Metalliferous mine dusts, and associated potentially toxic elements (PTEs) released into the environment through dust generating mining activities, is one such environmental pollution related cause of adverse health effects to humans. Despite occupational improvements within the mining industry, the release of metalliferous dusts into the environment remains a human health issue, especially in regions with poorly developed regulatory systems and where historic mining has left a significant legacy of exposed metalliferous mine wastes. The recovery of economically valuable metals present in historical waste materials also presents new technological and environmental challenges, whilst informal practices, such as those adopted in the artisanal mining of gold, also result in high levels of exposure to metals [14].

We review recent studies on the nature and hazard characterisation of metalliferous mine dusts (e.g. their main sources, composition and characterisation). Many factors influence the health effects of metalliferous mining dusts and understanding the exposure pathways is critical, as is the source, transport pathway, nature of the exposure (e.g. duration, activity) and exposure route (i.e. by inhalation, ingestion or dermal/topical absorption). The amount of any substance taken into the body that ends up active within the body is also an important consideration in the assessment of risk. The dose taken in by inhalation, ingestion and touch may not be the same as that retained within the body as varying amounts can be excreted quickly by different routes, usually through the liver, kidney or gastrointestinal tract, but sometimes in sweat, skin cells and hair loss [13].

Whilst the underpinning toxicology is pivotal, it is not the only driver of health outcomes following exposure, and we broaden an often narrowly framed health perspective to consider other potential determinants of disease, such as the role played by genes, lifestyle choices, and the wider socioeconomic context. Where we make reference to the underlying toxicological data and biological processes that underpin many of the related health disorders, we do not do so in detail. Readers are referred to the key public health and medical literature on which this review has drawn.

Consideration needs to be given to the fact that each location, and each population, are different, as are the variety of exposure scenarios (e.g. occupational exposure, neighbourhood exposure, population exposure), further complicated by differences in the management of the hazards. The complex nature of, and exposure to, metalliferous mine dusts requires approaches that take this complexity into account if we are to correctly apportion and mitigate the impacts on human health. There is a key role here for those working at the public-environmental health nexus to (i) develop a better understanding of the common predicators of ill health, (ii) to identify how to recognise which differences (be they individual, social, cultural, environmental) need special attention, and (iii) harness advances in laboratory sciences and technology to better utilise big data to support these needs. We highlight the challenges, as well as the opportunity, for new integrated environmental health tools to support future management.

\section{Source and Environmental Pathways of Metalliferous Mine Dusts}

PTEs frequently associated with mined deposits, or as gangue minerals in ore deposits, include arsenic (As), cadmium (Cd), chromium $(\mathrm{Cr})$, cobalt $(\mathrm{Co})$, copper $(\mathrm{Cu})$, lead $(\mathrm{Pb})$, mercury $(\mathrm{Hg})$, nickel $(\mathrm{Ni})$, uranium $(\mathrm{U})$, and zinc $(\mathrm{Zn})$, (Table 1). Whilst several of these PTEs (such as $\mathrm{Cu}$ and $\mathrm{Zn}$ ) are essential for life, this paper only considers toxic or excess exposures. Due to their high toxicity, $\mathrm{As}, \mathrm{Cd}, \mathrm{Hg}$, and $\mathrm{Pb}$ rank among the top 10 priority substances that are of public health concern ([12]-2018). Other priority elements for human health concern, and of particular relevance when considering exposure to metalliferous mine dust, include $\mathrm{U}$ and the transition metals $\mathrm{Co}, \mathrm{Cu}, \mathrm{Ni}$ and $\mathrm{Zn}$ due to their ability to generate reactive oxygen species (ROS) in biological tissues via Fenton-type reactions [25, 48, 63]. The Fenton reaction refers to the reaction between hydrogen peroxide and ferrous salts to produce a reactive species capable of oxidising a wide variety of organic substrates. In addition, we also include iron $(\mathrm{Fe})$ as Fe-bearing minerals are commonly found in mining dust and Fe oxides found in dust are potential contributors to inflammation in the human lung [43]. The common crystalline and amorphous phases of these PTEs found in ores or/and minerelated wastes are listed in Table 1. Mining activities provide multiple pathways for both the generation and distribution of mineral dusts into the environment. Dusts are released from a range of mining-related activities such as removal of the overburden, extraction and refining operations (e.g. smelter emissions; slag piles and tailings), and other ore-handling operations [23], all creating large volumes of dust that are readily mobilised by aeolian (wind-related) processes and can result in atmospheric transport over large distances [59]. Dust generation also occurs when transporting wastes, both on haulage roads within, and around, the mines, but also over longer distances such as along train lines [61]. Widespread contamination associated with airborne emissions from active and legacy mining and smelting operations is well documented in the literature, reported across a wide range of sampled media, including attic dust [16, 21]; house dust [75]; atmospheric dust [49•]; road dust [97•]; crop/ vegetables [101]; surface and groundwater [94], with mining- 
Table 1 Potentially toxic elements (PTEs) in metalliferous mine dust and the common crystalline and amorphous bearing phases

\begin{tabular}{|c|c|}
\hline PTE & Common bearing phases \\
\hline As & $\begin{array}{l}\text { Arsenopyrite }(\mathrm{FeAsS}) \text { is the main As ore mineral and is } \\
\text { often found in gold ores; scorodite and iron arsenate }\left(\mathrm{Fe}_{3} \mathrm{AsO}_{7}\right) \\
\text { are secondary phases in tailings }{ }^{1} \text {; calcium arsenate on fly ash was } \\
\text { found to be associated to the combustion of pyrite enriched coal; } \\
\text { arsenic trioxide in particulate form was found in close proximity } \\
\text { to smelters and roasters. }\end{array}$ \\
\hline $\mathrm{Cd}$ & $\begin{array}{l}\text { The primary ore of cadmim is the zinc mineral sphalerite; other } \\
\text { important Cd-bearing minerals are greenockite }(\mathrm{CdS}) \text { and hawleyite } \\
(\mathrm{CdS}) ; \mathrm{Fe} \text { oxides such as pyrite usually contain important amounts of } \mathrm{Cd}^{3}\end{array}$ \\
\hline Co & $\begin{array}{l}\text { Cobalt is almost always a by- or co-product of mining for other base metals, } \\
\text { chiefly nickel and copper; cobaltiferous iron sulphides include pyrite }\left(\mathrm{FeS}_{2}\right) \\
\text { and pyrrhotite }(\mathrm{Fe}, \mathrm{Co})_{1-\mathrm{x}} \mathrm{S} \text {; other Co-bearing sulphides are cobaltite }(\mathrm{CoAsS}) \text {, } \\
\left.\text { erythrite }\left(\mathrm{Co}_{3}(\mathrm{AsO})_{4}\right)_{2} \cdot 8 \mathrm{H}_{2} \mathrm{O}\right) \text {, carrollite } \mathrm{Cu}\left(\mathrm{Co}, \mathrm{Ni}_{2} \mathrm{~S}_{4} \text {, linnaeite } \mathrm{Co}_{3} \mathrm{~S}_{4} \text {, pentlandite }\right. \\
(\mathrm{Fe}, \mathrm{Ni}, \mathrm{Co})_{9} \mathrm{~S}_{8} \text { and siegenite }(\mathrm{Co}, \mathrm{Ni})_{3} \mathrm{~S}_{4}{ }_{4} \text {. }\end{array}$ \\
\hline $\mathrm{Cr}$ & $\begin{array}{l}\text { Chromite is by far the most industrially important mineral for the production of } \\
\text { metallic chromium; magnesiochromite }(\mathrm{MgCr} 2 \mathrm{O} 4) \text { is a minor ore mineral. } .^{5}\end{array}$ \\
\hline $\mathrm{Cu}$ & $\begin{array}{l}\text { Chalcopyrite }\left(\mathrm{CuFeS}_{2}\right) \text {, chalcocite }\left(\mathrm{Cu}_{2} \mathrm{~S}\right) \text {, and bornite }\left(\mathrm{Cu}_{5} \mathrm{FeS}_{4}\right) \text { are important ores; } \\
\text { siderite }\left(\mathrm{FeCO}_{3}\right) \text {, cuprite }\left(\mathrm{Cu}_{2} \mathrm{O}\right) \text {, malachite }\left[\mathrm{Cu}_{2}\left(\mathrm{CO}_{3}\right)(\mathrm{OH})_{2}\right] \text {, azurite } \\
\left(\mathrm{Cu}_{3}\left(\mathrm{CO}_{3}\right)_{2}(\mathrm{OH})_{2}\right) \text {, are minor copper ores. }\end{array}$ \\
\hline $\mathrm{Fe}$ & $\begin{array}{l}\text { Pyrite }\left(\mathrm{FeS}_{2}\right) \text {, haematite }\left(\mathrm{Fe}_{2} \mathrm{O}_{3}\right) \text {, magnetite }\left(\mathrm{Fe}_{3} \mathrm{O}_{4}\right) \text {, goethite }[\alpha-\mathrm{FeO}(\mathrm{OH})] \\
\text { and limonite }\left(\mathrm{FeO}(\mathrm{OH}) \cdot \mathrm{n}\left(\mathrm{H}_{2} \mathrm{O}\right) \text { are important ores; pyrite } \mathrm{Fe} \text { oxides and } \mathrm{Fe}-\mathrm{Mn}\right. \\
\text { oxyhydroxides are common hosts of PTEs such as As, } \mathrm{Cu} \text { and Ni. }{ }^{2,7}\end{array}$ \\
\hline $\mathrm{Hg}$ & $\begin{array}{l}\text { Cinnabar }(\mathrm{HgS}) \text { is the main ore mineral; others include elemental mercury, } \\
\text { corderoite }\left(\mathrm{Hg}_{3} \mathrm{~S}_{2} \mathrm{Cl}_{2}\right) \text {, schwartzite }\left[(\mathrm{HgCuFe})_{12} \mathrm{Sb}_{4} \mathrm{~S}_{13}\right] \text {, and livingstonite } \\
\left(\mathrm{HgSb}_{4} \mathrm{~S}_{7}\right)^{8} ; \text { coal mining wastes have high } \mathrm{Hg} \text { contents }{ }^{9} \text {; loss of elemental } \\
\mathrm{Hg} \text { occurs during amalgamation processing of ore from lode and placer } \\
\text { Au deposits. }{ }^{10}\end{array}$ \\
\hline $\mathrm{Ni}$ & $\begin{array}{l}\text { Pentlandite }\left[(\mathrm{Fe}, \mathrm{Ni})_{9} \mathrm{~S}_{8} .\right] \text { is the most important nickel sulphide mineral and is } \\
\text { often associated with nickel-containing pyrrhotite and chalcopyrite. Other } \\
\text { nickel-bearing minerals include nickeliferous limonite, nickeliferous goethite, } \\
\text { siegenite, and millerite; Ni-Fe alloys, glass and olivine were found in waste } \\
\text { dusts (slags, fly ash) generated by laterite Ni ore smelting. }{ }^{11}\end{array}$ \\
\hline $\mathrm{Pb}$ & $\begin{array}{l}\text { Galena }(\mathrm{PbS}) \text { is the main lead ore mineral; anglesite }\left(\mathrm{PbSO}_{4}\right) \text {, cerussite }\left(\mathrm{PbCO}_{3}\right) \text {, } \\
\text { coronadite }\left(\mathrm{Pb}_{2} \mathrm{Mn}_{8} \mathrm{O}_{16}\right) \text { and pyromorphite }\left(\mathrm{Pb}_{5}\left(\mathrm{PO}_{4}\right)_{3} \mathrm{Cl}\right) \text { are common } \\
\text { secondary phases. }\end{array}$ \\
\hline $\mathrm{U}$ & Uraninite $\left(\mathrm{UO}_{2}\right)$ is the most important ore of uranium; other U-bearing minerals \\
\hline \multirow[t]{2}{*}{$\mathrm{Zn}$} & $\begin{array}{l}\text { include autunite }\left[\mathrm{Ca}\left(\mathrm{UO}_{2}\right)_{2}\left(\mathrm{PO}_{4}\right)_{2} \cdot 10-12 \mathrm{H}_{2} \mathrm{O}\right] \text {, coffinite }\left[\mathrm{U}\left(\mathrm{SiO}_{4}\right)_{1-\mathrm{x}}(\mathrm{OH})_{4 \mathrm{x}}\right] \\
\text { carnotite }\left(\mathrm{K}_{2} \mathrm{O} \cdot 2 \mathrm{UO}_{3} \cdot \mathrm{V}_{2} \mathrm{O}_{5} \cdot \mathrm{nH}_{2} \mathrm{O}\right) \text {, tyuyamunite }\left(\mathrm{CaO} \cdot 2 \mathrm{UO}_{3} \cdot \mathrm{V}_{2} \mathrm{O}_{5} \cdot \mathrm{nH}_{2} \mathrm{O}\right) \\
\text { schoepite }\left[\left(\mathrm{UO}_{2}\right)_{8} \mathrm{O}_{2}(\mathrm{OH})_{12} \cdot 12 \mathrm{H}_{2} \mathrm{O}\right] \text {, torbernite }\left[\mathrm{Cu}\left(\mathrm{UO}_{2}\right)_{2}\left(\mathrm{PO}_{4}\right)_{2} \cdot 8-12 \mathrm{H}_{2} \mathrm{O}\right] \\
\text { and uranophane }\left[\mathrm{Ca}\left(\mathrm{UO}_{2}\right)_{2}\left(\mathrm{HSiO}_{4}\right)_{2} \cdot 5 \mathrm{H}_{2} \mathrm{O}\right] .{ }^{14}\end{array}$ \\
\hline & $\begin{array}{l}\text { Sphalerite }(\mathrm{ZnS}) \text { is the main zinc ore mineral; sphalerite }(\mathrm{ZnS}) \text { is the main zinc } \\
\text { ore mineral; other } \mathrm{Zn} \text {-bearing minerals include hemimorphite }\left[\mathrm{Zn}_{4} \mathrm{Si}_{2} \mathrm{O}_{7}(\mathrm{OH})_{2} \cdot \mathrm{H}_{2} \mathrm{O}\right] \text {, } \\
\text { smithsonite }\left(\mathrm{ZnCO}_{3}\right) \text {, hydrozincite }\left(\mathrm{Zn}_{5}\left(\mathrm{CO}_{3}\right)_{2}(\mathrm{OH})_{6}\right) .{ }^{15}\end{array}$ \\
\hline
\end{tabular}

${ }^{1}[4] ;{ }^{2}[72] ;{ }^{3}[110] ;{ }^{4}[50] ;{ }^{5}[18] ;{ }^{6}[80] ;{ }^{7}[74 \bullet] ;{ }^{8}[87] ;{ }^{9}[6] ;{ }^{10}[7] ;{ }^{11}[38] ;{ }^{12}[111] ;{ }^{13}[9] ;{ }^{14}$ Hettiarachchi et al. $2018 ;{ }^{15}[109]$ related particulates reported in soils adjacent to mines and across the towns of mining communities [44, ]. The unregulated informal recycling of the complex contaminant mixtures arising from Waste Electrical and Electronic Equipment (WEEE) also releases metalliferous dusts associated with precious metals and rare earth elements, mixed with organics and plastics found in such equipment [24•].

Wherever mining has taken place then there is a potential legacy of exposed wastes, the literature attests to multiple on- going health risks for people and the wider environment associated with many abandoned mine sites and un-remediated tailings. Many legacy sites contain relatively high concentrations of metals and metalloids, often up to several percent by mass, and the economic value of these metals and their role as part of a circular economy, are becoming increasingly recognised [30]. Where former mine sites and waste deposits are the focus for the recovery of economically valuable metals, then the industrial activity can be a more complex 
issue (i.e. re-working spoil heaps/lagoons/leachates) []. In addition, the materials have been weathered and subjected to a wide range of environmental conditions that have modified the original ore and gangue materials. In such contexts, the dusts generated are potentially different in their reactivity and hazard from the originally mined sources. Parallels can be drawn with the coal mining industry where changes in specific dust characteristics have been invoked to explain resurgence in diseases such as black lung in the Appalachians [10].

PTEs can be transferred from mine dust-impacted soil to the human body via unintentional ingestion of soil and the soil-plant-human food chain. Children are at particular risk of ingestion of contaminated soil due to their frequent handto-mouth activity. Children are also sensitive receptors since girls are born with all their eggs already in their ovaries: contamination of young girls affects their children and probably their grandchildren. Evidence also suggests that although sperm is generated daily after puberty, there is also transmission to the next generation of some early life exposures through epigenetic mechanisms, although the evidence is currently limited to obesity, stress, risk of diabetic death, cardiovascular diseases and the like $[40 \bullet \cdot$. It is possible that environmental metals may be added to known epigenetic toxins such as endocrine disruptors, but further work is awaited [71]. Furthermore, there is a difference between intergenerational (or parental) and transgenerational effects. The former include effects such as the impact of in utero exposure to toxins on the developing embryo and its germline, whilst the latter refers to effects found in generations not exposed to the initial exposure, e.g. great-grandchildren $[40 \bullet \bullet, 83 \bullet]$.

The relationship between outdoor mining-related metal contamination and the indoor residential environment remains poorly understood. Quantifying indoor concentrations of metals originating from mine waste is complex; however, house dust is an important route of exposure, particularly for children. Numerous studies highlight the increased risks for long-term residents of communities living close to active, re-activated and abandoned mine sites around the world (e.g. [115•]).

\section{Characterisation of the Complex Nature (Hazard) of Metalliferous Dusts}

Hazard, in this context, refers to the inherent properties of the mineral dust that have the potential to cause harm. Epidemiological and toxicological studies have indicated that the hazard posed by mineral dusts depends not only on their abundance and particle size but other properties such as their chemical composition, solubility, shape, structure and surface area of the inhaled particles, which all play a role in the associated toxic, carcinogenic or other health effects $[88 \bullet, 89 \bullet]$. Furthermore, whilst we hypothesise that organs such as the lungs where already damaged by disease processes will be more susceptible to the absorption of metals and other toxins, to the authors' knowledge little is known about how existing disease affects the outcome of exposure to metalliferous dusts.

In relation to dusts, size matters. Whilst most mining operations generate coarse dust $(\geq 2.5 \mu \mathrm{m}$ diameter), hightemperature processes, such as smelting and coal combustion, are typically associated with the generation of fine particulates $(\leq 2.5 \mu \mathrm{m})$ [31]. This fine fraction can travel long distances and an understanding of respiratory tract anatomy, physiology and clearance mechanisms are also important to understand the exposure and dose. The respiratory tract in humans is typically split into three regions (after [27••]): (1) the extrathoracic region, which includes the nasopharynx and airways to the larynx. There is also the potential for the direct transfer of particulate matter (PM) through the olfactory (smell) nerves from nose to brain (2) the tracheobronchial region, which consist of the large upper airways from the larynx down to before the terminal bronchiole, with the upward mucociliary transports, and (3) the pulmonary region, defined as the terminal bronchioles and the alveoli. Following inhalation, the larger inhaled particles become trapped in the mucus that lines the airways and are transported (by tracheobronchial cilia) and expectorated or swallowed into the gastrointestinal pathway. Particles $<4 \mu \mathrm{m}$ are respirable (i.e. deposit in the alveoli). The lungs act as a continuous sampler of inhaled PM. Humans are oronasal breathers, and there is less filtering of PM inhaled through oral breathing compared to nasal breathing. With greater exertion, more oral breathing results, and thus ventilation rates and activity patterns need also to be considered in different modelling exposure scenarios.

Whilst a growing body of literature underlines the increasing concern for the impact of dust $\mathrm{PM}$, especially the $<\mathrm{PM}_{2.5}$, ${ }_{1}$ and ${ }_{0.1}$ fraction, on human health, to understand the nature of the hazard posed the mineral dust should be suitably characterised. Growing acceptance that the physicochemical nature of the PM influences the deposition, dissolution and distribution to other parts of the body, and ultimately the toxic effect, has seen an expansion in approaches to PM characterisation to explore the chemistry, oxidation states and material structure [48]. Synchrotron-based X-ray fluorescence and Xray absorption spectroscopy (XAS) are increasingly being used to map the mineralogy, phase composition, elemental associations, and oxidation states of a range of elements contained within the PM, whilst the use of sequential chemical extractions remains a popular tool for solid-phase speciation (e.g. [93, 110]).

The need to utilise multiple techniques to reveal the complex nature of these dusts, and the complex nature of the interaction with health, is now widely recognised. The exposome is one such approach [32•]: the total exposure of a person from conception to death and the resulting health impact. Although complex, with needs for identified biomarkers, 
new statistical and analytical approaches, and often based on large datasets, the exposome can also work with smaller samples (435 adolescents, 19 metals: [85•]). Our classification of determinants of disease is similar to the current classification of the exposome: internal, specific external, general external [32•], but focussed on metalliferous dusts and mining (Fig. 1).

A growing body of work highlights examples of in vivo reactions that can generate an overabundance of reactive oxygen species (ROS), reactive nitrogen species (RNS) and lipid peroxidation in the body. Reactive molecules are pivotal to control cellular responses focusing on inflammatory settings and associated with many pathological conditions such as chronic inflammation, atherosclerosis, diabetes, inflammatory bowel disease and autoimmune diseases [86]. ROS are necessary intracellular signalling molecules which regulate a wide variety of physiology; however, an overabundance of ROS can lead to oxidative stress within the body. Fe-rich particles may also contribute to increased ROS formation. Iron exhibits $\mathrm{Fe}^{3+}$ and/or $\mathrm{Fe}^{2+}$ forms in crystalline oxides and inhalation into the human lung of Fe-containing particles has been associated with the release of free radicals [67•]. Magnetite has been reported to be a more effective catalyst for Fenton reactions and the production of $\mathrm{OH}$ radicals than goethite or haematite. The iron oxidation state of most natural iron oxide minerals such as goethite and haematite is $3+$, whilst magnetite has a combination of $\mathrm{Fe}^{2+}$ and $\mathrm{Fe}^{3+}$ oxidation states; the reaction rate of $\mathrm{H}_{2} \mathrm{O}_{2}$ with $\mathrm{Fe}^{2+}$ sites is significantly higher than the rate with $\mathrm{Fe}^{3+}$ sites [92]. Oxidative stress can result in a range of negative outcomes, including DNA damage, chronic inflammation in the lungs [82] and cardiovascular disease [58••].

'Risk' is the possibility of harm arising from a particular exposure to a substance or substances, under specific

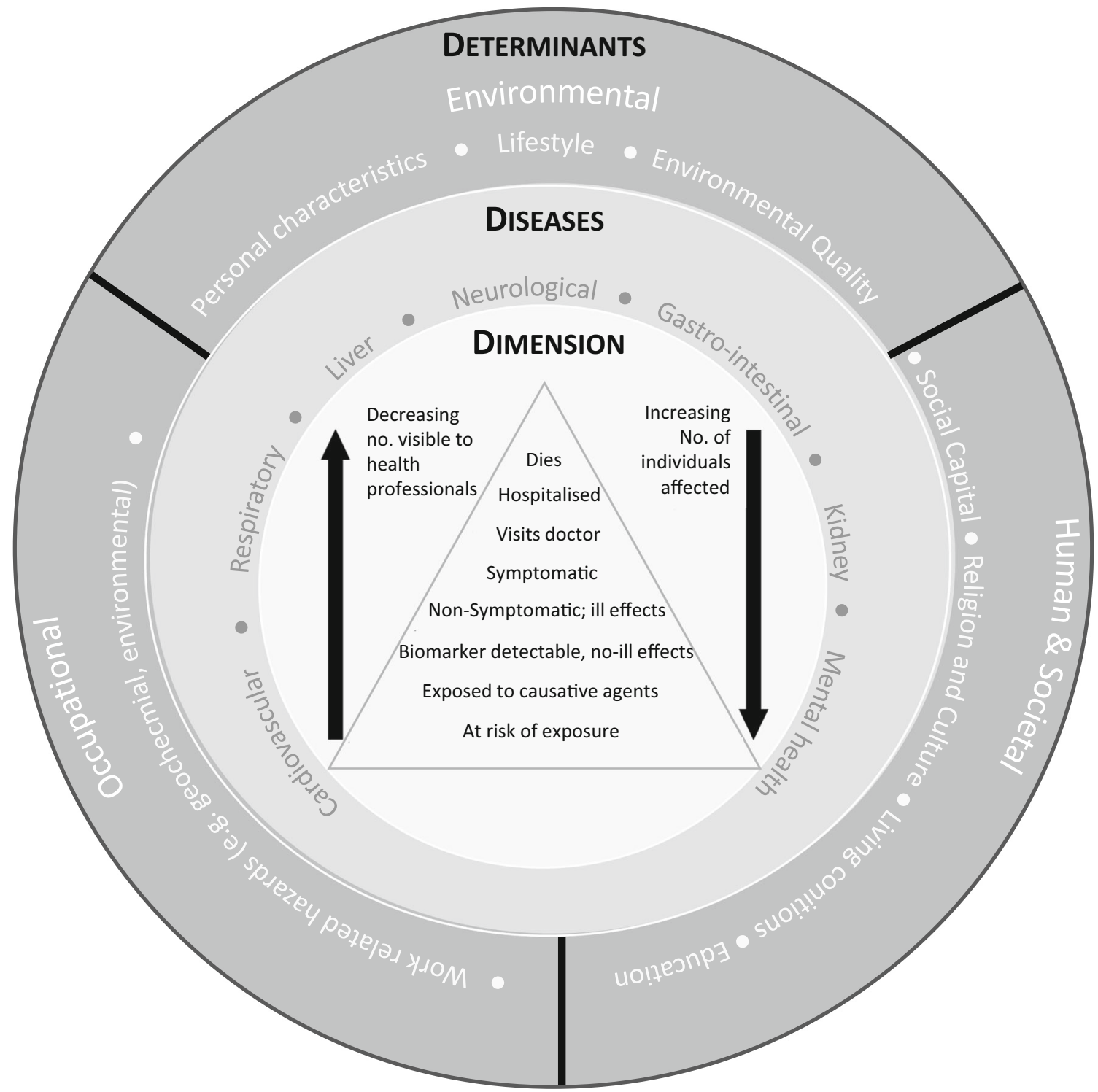

Fig. 1 Mining-related determinants of disease, associated diseases, and dimension (scale) of the disease burden (the 'disease pyramid' $($ is after [96••]) 
conditions. In assessing risk to humans following exposure to a contaminant, it is the quantitative pattern of the deposition, and subsequent bioavailability (uptake), that influences the dose, and ultimately the toxic effects, rather than the exposure concentration (intake) per se [27••]. For the inhalation pathway, we need to understand the behaviour of inhaled particles; not just the initial dose but how the PM is cleared and redistributed within the body. Significant research has focussed on the development of in vitro non-animal testing and biomonitoring methodologies to provide human-relevant data for decision support in risk assessments and notable recent approaches are outlined below.

\section{Physiologically-Based In vitro Lung Bioaccessibility Protocols}

In vitro bioaccessibility refers to that portion of the contaminant which can be extracted and released during passage through the human system being represented/modelled and is thus available for uptake. Several in vitro protocols have been developed, such as the BARGE UBM [106] and US EPA glycine method [99] for oral bioaccessibility modelling. Despite the often complex dissolution kinetics, in vitro oral bioaccessibility protocols may be used as an indicator of in vivo bioavailability, with mathematical equations relating in vitro bioaccessibility to in vivo bioavailability for a range of soil types, sources and PTEs. Similar in vitro-in vivo validation for inhalation bioaccessibility protocols are still lacking. Boisa et al. [22] highlight some of the many problems with using simulated lung fluids. Nonetheless, the last two decades have seen a proliferation of experiments using simulated lung fluids. This research has predominantly focussed on two main types of fluids: those representative of the neutral extracellular environment in the interstitium of the lungs (i.e. Gamble's Solution (GS) believed to mimic the interstitial conditions of the lungs; the interstitium is the space between cells, a matrix of collagen bundles interspersed with fluid), or the more acidic artificial lysosomal fluid (ALF) which simulates the environment within the spaces of the pulmonary alveolae where cells engulf and metabolise particles. This research, whilst predominantly on air pollution (which contains combustion-related metals and hence of relevance), highlights that particles deposited in the lungs that are not readily solubilised by the epithelial lining fluids (i.e. the fluids covering the lung lining) will be subject to phagocytosis by the pulmonary alveolar macrophages. Complexation with biological components in the lung fluids can also influence dissolution rates [22], and once dissolved can negatively impact the immune system [36, 100].

Different solubilities and dissolution rates in different body fluids [44, 57], interactions of complex chemical mixtures [26.], and the role of enzymes, mucoproteins and surfactants are increasingly being investigated $[19,65]$. The role of mineralogy and soil-phase speciation in the bioaccessibility and bioavailability of metals in PM is well documented [38]. U-enriched aeolian dusts in the proximity of two $U$ mines in New Mexico highlights the differential solubility of U minerals; uraninite and carnotite are more soluble in the GS compared to the more acidic ALF [49॰]. Whilst such extraction protocols still need in vivo validation, the authors demonstrate the extracts accord with a geochemical model (PHREEQC). Acknowledging the potential continuation of metal(loid) dissolution once the PM is cleared from the lungs and/or has passed through the gastrointestinal tract has rarely been addressed. Kastury et al. [57] recently proposed an inhalationingestion bioaccessibility assay, designed to be biologically relevant to a human inhalation scenario.

\section{In vitro Inhalation Toxicity Testing Using Cell Cultures}

Non-animal models of epithelial barriers (skin, intestinal and pulmonary context) play a critical role for in vitro to in vivo extrapolation. Immortalised human adenocarcinoma cell lines (such as Caco-2 or T84) help to study absorption mechanisms, as do immortalised cell lines (e.g. BEAS-2B cells) and primary epithelial cells (e.g. normal human bronchial epithelial cells). However, as adenocarcinoma cell lines are derived from tumours, which by their nature are less representative of typical conditions, the intestinal epithelial cells may potentially offer a more physiologically relevant cell-based approach [42••].

The inflammatory stress response (ISR, used as a measure of particle toxicity) was investigated in human lung epithelial cells following exposure to a range of metal-sulphide ore minerals: the role of Fenton and other heavy metals was highlighted, whilst copper-bearing ore minerals, containing ferrousiron, produced the largest ISR [48]. An earlier study highlighted the role of pyrite in coal workers' pneumoconiosis with pyrite-free coal producing the same limited ISR as exposure to inert organic matter [47].

The elevated presence of ROS can lead to oxidative damage of biomolecules, in turn, linked to a range of diseases including cancer, respiratory, neurodegenerative and digestive disorders $([58 \bullet \bullet, 66])$. The body's stress response to ROS can also generate excess ROS in the lungs, engendering a vicious negative cycle. The oxidative potential of $\mathrm{PM}_{10}$ in urban air samples collected on filters across Lanzhou using plasmid scission assay (PSA), in tandem with total and water-soluble metal extraction, showed a negative relationship between $\mathrm{TD}_{20}$ (toxic dose of particles necessary to damage $20 \%$ of DNA) and all of the metals investigated, with the watersoluble $\mathrm{Cu}, \mathrm{Zn}$, As and $\mathrm{Mn}$ exhibiting relatively strong negative correlations [108]. The inference being that the watersoluble metals associated with $\mathrm{PM}_{10}$ were primarily responsible for the oxidative potential and plasmid DNA damage. A better understanding of the mechanisms that lead to toxicity can help in developing better in vitro models. 


\section{Biomonitoring}

Biomonitoring (the measurement of a chemical or its metabolites in body tissues and fluids) data can improve our understanding of exposure. It can contribute to a multiple lines of evidence approach and allow a better understanding of how our bodies interact with the environment. Furthermore, biomonitoring studies have the potential to guide risk management decisions for all legacy mining communities into the future. The case for biomonitoring data in improved enforcement of health and safety legislation to protect both workers and the wider community against the hazards posed by mining activities is clear [77•].

Correlations between PTEs in household dust and children's hair, in two different environmental settings (mining district; suburban non-mining area), showed significantly higher indoor dust and hair concentrations of PTEs in the mining district [17]; a significant exposure-biomarker association was found, particularly for $\mathrm{Pb}$. Socio-economic determinants related to unpaved roads and the physical environment of the households increased the exposure to PTEs by promoting dust accumulation indoors. Furthermore, a child's behaviour may be a modulating factor in the exposure to PTEs, as the correlation between $\mathrm{Pb}$ in dust and $\mathrm{Pb}$ in hair was stronger for children who played with dirt (soil) in the mining neighbourhood. Dust particulates adhering to clothing and shoes can easily be carried by the children into their home environment [17]. In villages surrounding the Huodehong leadzinc mine, women showed significantly $(p<0.01)$ higher hair contents than men for the same PTEs, probably due to differences in individual exposure frequencies and exposure characteristics, metabolism, and physiology [101] (cf. Fig. 1).

\section{Determinants of Disease in Mining Communities}

Mining, like any industry or exposure, has its share of diseases specifically related to the type of mine, the particular industrial processes and the workforce connected to each mine. The role of metalliferous mine dust in the aetiology of these diseases needs to be seen in relation to a broad view of possible determinants of disease: individual, social, economic and environmental factors which may interact as they impact people's health [64]. These determinants operate on scales ranging from the individual (e.g. sex, age, genetics) to the international (e.g. policies and regulations). For example, the development of pneumoconiosis among miners depends on the chemical composition of dust, fineness of dust, air concentration of dust, but also length of period of exposure and underlying health status of the exposed worker $[46,66]$. We use three broad classes of determinants (occupational, environmental, human and societal) to illustrate the complex interplay of considerations and issues that influence disease (Fig. 1).

\section{Occupationally Related Determinants}

The mining industry is known for its highly risky and hazardous working environment. Occupational hazards relevant to disease associated with metalliferous mine dusts include the following:

Chemical The unrestricted use of metals can lead to high levels of exposure to a range of PTEs. For example, the use of elemental mercury in small-scale artisanal gold mining leads to methyl-mercury pollution of the local environment and ingestion through the locally grown diet. Inhalation of elemental $\mathrm{Hg}$ by the children and other workers, often working in kitchens away from the actual mine, is an issue [14].

Environmental Adverse environmental conditions such as absence of natural light, fresh air, and high dust volumes contribute to mental stress and ill health as well as diseases specific to the dust characteristics and metal content.

Social and Managerial Risks Managers' attitudes to safety and miners' roles affect health outcomes [52, 114]. Psychological stress levels in Australian miners were higher than in non-mine workers, with alcohol use, work role (as managers), level of work satisfaction, financial factors and job insecurity contributing factors. Added to this was a perception of lower workplace support for people with mental health problems [29••].

Personal The interaction of psychological stress with exposure to traffic PM is synergistic [5•]. It can be expected that mining dust acts similarly when added to psychological stress. Age and sex affect health, with children and women showing different vulnerabilities from men due to different biochemical and physiological characteristics. Miners in regulated industry are usually adults between school leaving age and retirement, with men more likely in many countries to be working at the mine face and women in less physically demanding posts, each with differing exposures to toxins and other disease determinants. Older miners are likely to have longer exposures to dust and toxins. In artisanal and small-scale mining, children are found working directly in the mines, or more likely in the recovery processes; for example, exposed to $\mathrm{Hg}$ in the amalgamation process in gold extraction.

\section{Environmental Determinants}

Wider Environmental Quality Pollution of water, soil, or air by $\mathrm{PM}$ of the wider inhabited area around a mine can affect the local food sources and hence diet, with immediate and longterm effects $[1 \bullet]$.

Living Condition Deprivation is a major determinant of ill health. Mining wastes, the poor and deprived, and the most vulnerable members of the community are often found in juxtaposition. 
Exposed communities commonly comprise historically marginalised ethnic groups living in informal settlements, state, or Government-supported housing and retirement homes (e.g. [64]). Living near a mine and spoil or a metal-emitting industry put people at risk of exposure to PM and associated metals ('neighbourhood exposure') [35]. Elderly people exposed to mining waste, which is often open to being spread widely by wind and rain, suffer a disproportionate burden of lung diseases [78•]. Family and friends can be exposed ('bystander exposure') to dust brought home on clothes, and develop related diseases including $\mathrm{Pb}$ poisoning or lung cancer.

\section{Human and Societal Determinants}

Individual Characteristics and Inheritance (e.g. Genetic) Gender, age and genetic inheritance contribute to vulnerability to the effects of exposure to environmental pollutants. Children's unique physiology, development and behaviour can influence the extent of their exposure [13]. Children are not small adults; they differ from adults in their exposures and may differ in their susceptibility to hazardous chemicals, sometimes more, sometimes less. It is unlikely that a set of genes exist which give an easy molecular signature for toxicity to metals or other mined commodities. Nevertheless, genetic diversity clearly modifies the body's response to various exposures, even if the evidence is not detailed. Specific genes have been associated with coal workers' pneumoconiosis susceptibility [66], or protection [46] in a Chinese population, and decreased lung function in smokers living in the vicinity of Indian coal mines [34]. However, distinguishing between genes, epigenetic switches and socio-economic status ("nature and nurture") can be difficult and will take much more work: developing the exposome should help.

Personal and Lifestyle Choice Smoking can increase susceptibility to silicosis in miners [102], whilst nutritional status enhances or reduces the absorption of metals following exposure. For example, poor nutrition increases $\mathrm{Pb}$ absorption and toxicity [73]. Employment and housing in or near mines or places affected by metalliferous dusts may reflect lifestyle choices or the lack of them, easily compounded by related deprivation and socio-economic issues.

Health Care The level of emergency medical services infrastructure and preparedness differs significantly between countries [37]. Furthermore, non-emergency health care, where available, is typically focused on treatment, when a more fundamental need is prevention.

Social Capital Family and friends and the culture of the home community can put implicit or explicit pressure on workers to keep earning despite poor working conditions, and poor health, thus increasing exposure to dust and toxins, while adding to stress. In contrast, social mobilisation can drive positive changes and good social support is health protective [70].

Education Education affects health in the long term, at the individual, community and wider society levels, through complex personal and social interactions [113*0]. Education can improve health through a multitude of channels: greater ability to access information and services, proficiency to navigate bureaucracies, greater political participation and voice [60॰]. Many miners suffer a lack of education, which limits their job prospects, pushing them into artisanal mining and trapping them in poverty [104].

National and International Context In many ways, the global economy /trade has the biggest impact on health from mining given its influence on the 'safety climate' [37]. Furthermore, national health and safety regulations may exist, but be poorly complied with, often due to (global) economics. Mines that followed the US Mine Safety and Health Administration (MSHA) guidelines were less likely to report lung disease [112]. The dynamics of human populations in mining communities also has a role to play, such as the length of time spent in the affected area, nature of community infrastructure, i.e. old productive versus new and transient mining activity.

\section{Health Outcomes and Response}

Ill health may be visualised as a pyramid (dimension (scale) of the disease burden, Fig. 1 innermost circle) with decreasing numbers from those at risk of exposure to those who die. The number of people dying is easier to ascertain than the number of those exposed, although apportioning a cause of death to specific disorders and pathological processes can be tricky [3].

There is increasing evidence of a link between environmental pollution and preventable diseases, especially in developing countries. A comprehensive review of published epidemiological literature investigating environmental chemical exposure in Thai children concluded that exposure to PTEs (including $\mathrm{As}, \mathrm{Pb}, \mathrm{Cd}$ ) in industrial and mining areas is one of three main types of chemical exposure, together with pesticides and air pollution. Major health outcomes included detrimental effects on cognitive function and cancer risk. Furthermore, the authors pointed out increasing concern, but little acknowledgment, about the effects of chronic mining-related exposure to PTEs such as As [91].

Exposure to PM can initiate or enhance disease in humans. With respect to cancers, then $\mathrm{Cr}, \mathrm{Ni}$ and As are known carcinogens, whilst the evidence is less clear for $\mathrm{Pb}$ and $\mathrm{Fe}$ (cf. Table 2) $[12,84 \cdot \bullet, 105]$. The consensus on $\mathrm{Pb}$ is that given its ubiquitous occurrence and many different forms it is hard to categorically evaluate its ability to cause cancer. The IARC $[51 \bullet \cdot]$ list $\mathrm{Pb}$ as 'possibly carcinogenic to humans' (IARC group 2B), inorganic $\mathrm{Pb}$ compounds as 'probably carcinogenic to humans' (IARC group $2 \mathrm{~A}$ ) and organic $\mathrm{Pb}$ compounds as 'not classifiable as to 


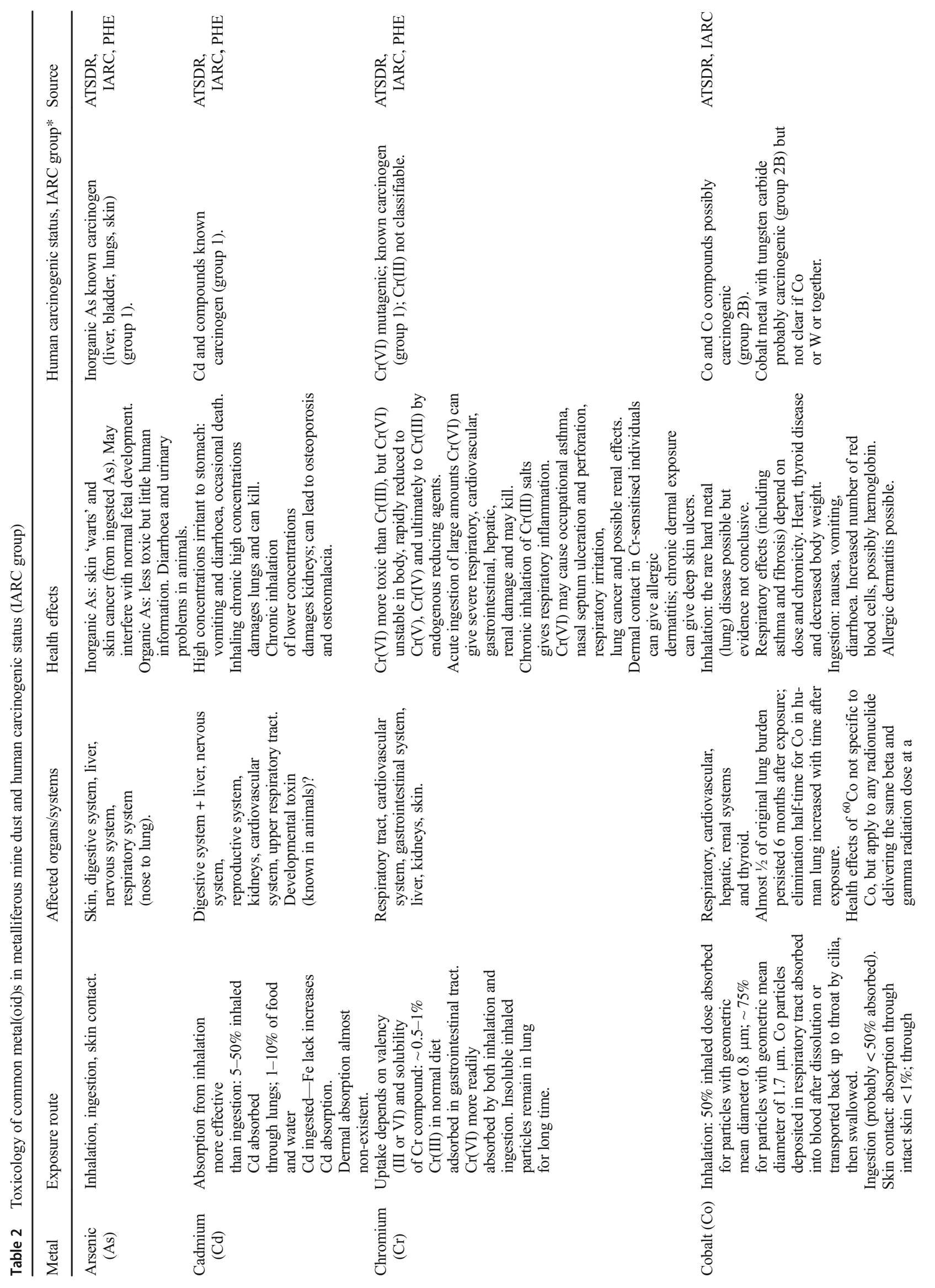




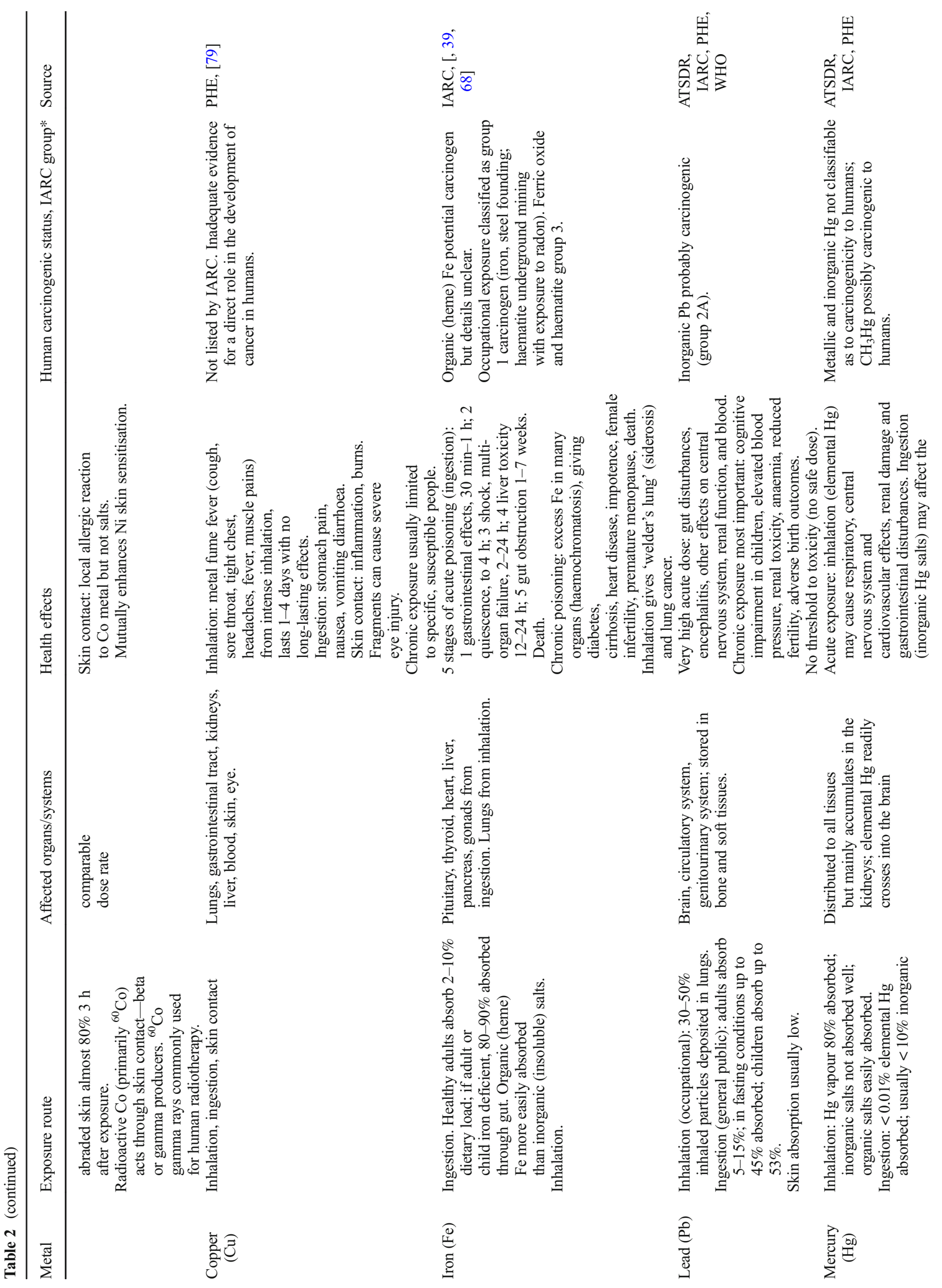




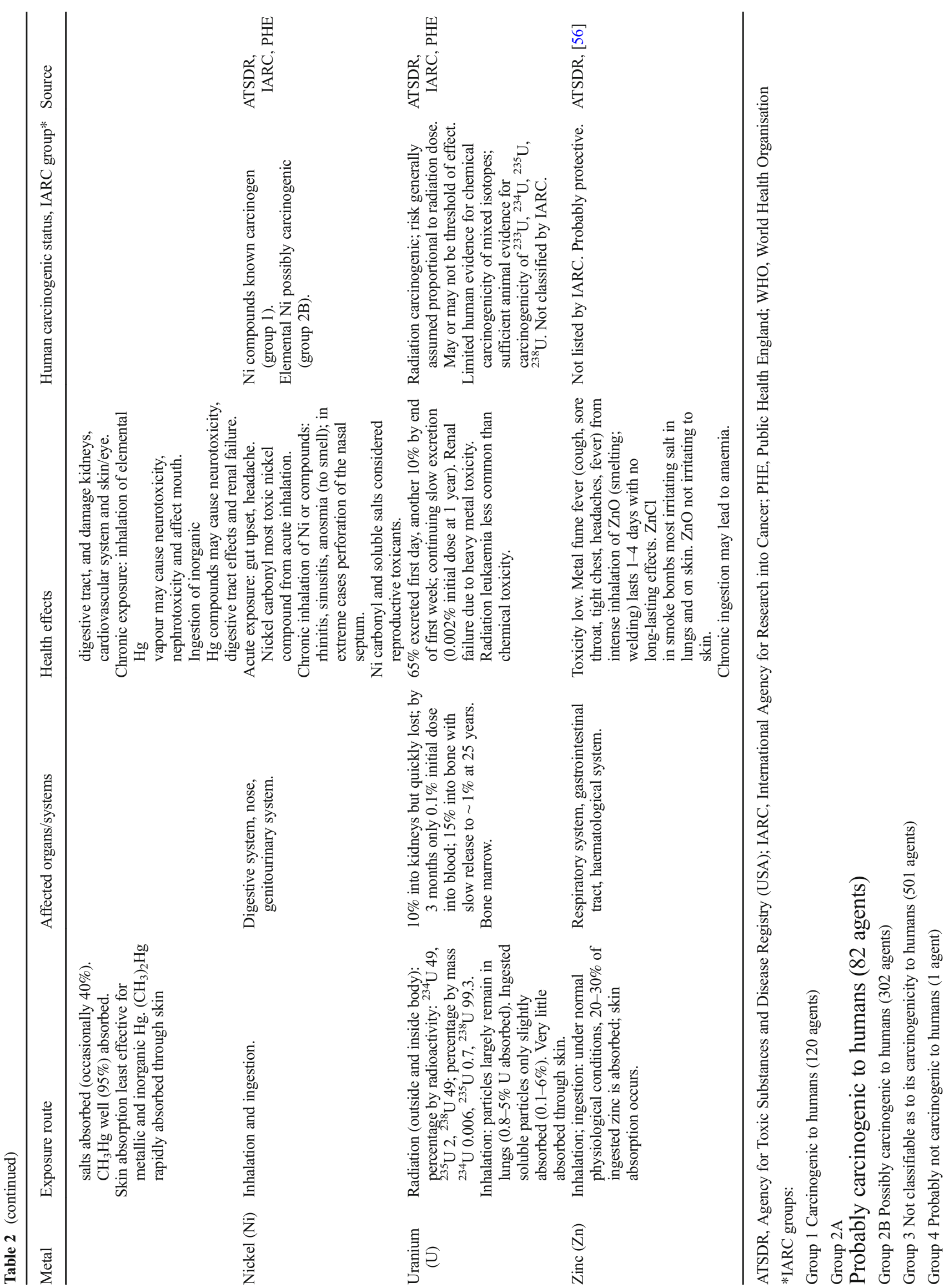


its carcinogenicity to humans' (IARC group 3), but may be metabolised to ionic, inorganic lead and so become $2 \mathrm{~A}$ (Table 2). Mining, however, can lead to an increased risk of contracting other diseases: increased pulmonary tuberculosis has been recorded in underground $\mathrm{Cu}$ miners in Zambia [76]. A high prevalence of wheeze (a symptom of asthma) and rhinoconjunctivitis has been noted among the elderly in communities located near mine dumps [78•]. Significantly increased risk of larynx cancer has been observed for many production and transport professions, including miners [15], possibly related to PM exposure.

Whilst an epidemiological association has been demonstrated between mortality and morbidity in lung cancer and cardiovascular diseases and exposure to PM the actual mechanisms of this relationship remain unclear. Chronic obstructive pulmonary disease (COPD), a slowly progressing disease characterised by a gradual loss of lung function, causes $4 \%$ of overall global disease burden [41••]. The most important risk factor is active smoking, but other risk factors are occupational or environmental (including coal and hard-rock mining), and socio-economic depravation in childhood [20].

Asthma, an inflammatory respiratory condition, is a major cause of disability, health care utilisation and reduced quality of life and accounts for approximately $1 \%$ of global overall disease burden $[41 \bullet \cdot]$. Inhaled PM induces oxidative stress leading to inflammatory responses in the airways and bronchial hyperreactivity and metal fumes are well-recognised causes of occupational asthma, but the contribution of metal dusts to nonoccupational asthma is less obvious. High blood $\mathrm{Pb}$ is correlated with having asthma in children, but the meaning is unclear [107]. Other diseases linked to metal exposures (with or without air pollution) include chronic neurological disorders such as Parkinsonism and Alzheimer's disease (including $\mathrm{Al}, \mathrm{Cu}, \mathrm{Mn}$,) [11•], renal and liver disorders (Table 2).

This multifactorial landscape generates a complex relationship between mining, metalliferous dusts and human health (Fig. 1). Differences in health outcomes occur both temporally and spatially and are overlain by differences in management of the hazard and in the extent of, and behaviours towards, regulatory compliance. Risk assessment and health and safety management are important elements of most industries, including mining, and have a significant role to play in reducing incidences of mining-related ill health. Risk management refers to all activities and procedures undertaken to manage the inherent risks of that particular industry. Risk management does not eliminate risk, but supports the identification of appropriate, and proportionate, strategies and control measures to manage them. Dust abatement strategies are the primary preventative measure and improved ventilation, more effective dust extraction systems, as well as water spraying systems have been linked to reduced incidences of mining-related diseases [55]. Regulatory limits are also important here, whilst safety organisations, workers' unions and senior managers also need to be active, not passive bystanders [114].

Current risk assessment guidance still principally focuses on a chemical-by-chemical approach, and have not kept pace with research into the possible synergistic or antagonistic toxicological effects of complex environmental mixtures [2]. A review of studies on the relationships between exposure to $\mathrm{Pb}$, As and $\mathrm{Cd}$ and neurodevelopmental outcomes in prenatal and early childhood identified the synergistic effect of combined mixtures on health outcomes [95]. There is also a need to build non-chemical stressors into our risk assessment models. Parallels can be drawn with air pollution studies where combined exposure to psychosocial stress and particulate air pollution has been shown to be worse than exposure to either alone [5•]. However, we acknowledge that there are chemical and physical differences between metalliferous mine dusts and traffic sourced PMs and so we need to be cautious about what can be safely inferred from traffic PM-related research.

Exposure to metalliferous dusts remains a significant environmental health concern, especially in many low- and middle-income countries where dust emitting industries are often less well regulated [60॰]. Whilst occupational exposure to metalliferous dust has long been recognised as potentially hazardous to workers health, community-wide interventions to protect vulnerable communities, including integrating biomonitoring and surveillance (e.g. miners' lung function) into existing health programs and surveys, need to be promoted alongside local and national-level environmental control policies [60॰]. Arquette et al. [8] describe a community defined risk assessment and risk management model, emphasising the important contribution Native people can bring in terms of traditional, cultural and ecologic knowledge of their environment. Semi-qualitative and qualitative research is also important for assessing and better targeting individuals' and at-risk subgroups risk perceptions and behaviours [45].

Future risk assessment approaches should strive to identify and integrate the effects of exposure to complex chemical mixtures, non-chemical stressors (such as socio-economic and cultural drivers), alongside individual differences (e.g. genetic variability). We are still a long way from a regulatory environment that drives the development of risk assessment methods that consider the breadth of potential stressors. The complex interplay of advances in scientific and technological capability, with economic and political drivers, all play a part, but a fuller commentary on this is beyond the scope of this review.

\section{Conclusions}

Research linking environment to human health is starting to mature, highlighting the subtlety of multiple exposures, mixtures of substances and the cumulative legacy effects of life in disrupted and stressed environments. We are developing more 
refined biomarkers of these responses which enhance our appreciation of the burden of effects on society and also direct us to more sophisticated investigation of risk assessment processes. Yet, the disparity of the global geography of disease burden remains a challenge. Combating environmental hazards has remained a major area of concern for the UN Sustainable Development Goals (SDGs, [98]). Despite $\sim 25 \%$ of global disease burden being related to environmental factors [], identifying health impacts from exposure to chronic/acute hazards from dust and understanding the complex relationship remains challenging. How we utilise and interact with our environment adds another layer of complexity. Academics could do more to develop evidence-based solutions to promote relevant preventive activities to issues around the sustainable extraction and use of mineral resources, working in partnership with government, industry and communities, at local, national and international scales [60•]. The development of a shared understanding of the research gaps, information access, and the needs of stakeholder/ user communities, together with the enablers and challenges, is vital to address local to global health and wellbeing challenges arising from environmental pollution, such as from mining- and mine-related metalliferous dusts. Research at the environmenthealth nexus has traditionally been viewed as too environmental for funding bodies in the geosciences, yet too environmentally focussed for health organisations and related charitable funders. We need to tackle this deficit if we are to embrace the 2030 Agenda for Sustainable Development and achieve the UN SDG of good health and wellbeing.

\section{Compliance with Ethical Standards}

Conflict of Interest Jane A. Entwistle, Andrew S. Hursthouse, Paula A. Marinho Reis, Alex G. Stewart declare that they have no conflict of interest.

Human and Animal Rights This article does not contain any studies with human or animal subjects performed by any of the authors.

Open Access This article is distributed under the terms of the Creative Commons Attribution 4.0 International License (http:// creativecommons.org/licenses/by/4.0/), which permits unrestricted use, distribution, and reproduction in any medium, provided you give appropriate credit to the original author(s) and the source, provide a link to the Creative Commons license, and indicate if changes were made.

\section{References}

Papers of particular interest, published recently, have been highlighted as:

- Of importance

•. Of major importance

1. Abdullah NH, Mohamed N, Sulaiman LH, Zakaria TA, Rahim DA. Potential Health Impacts of Bauxite Mining in Kuantan. Malays J Med Sci. 2016;23(3):1-8 Clearly illustrated review of the integration of mining processes, hazards, and impacts on environment, socio-economics and health.

2. Adebambo OA, Ray PD, Shea D, Fry RC. Toxicological responses of environmental mixtures: environmental metal mixtures display synergistic induction of metal-responsive and oxidative stress genes in placental cells. Toxicol Appl Pharmacol. 2015;289:534-41.

3. Adeyinka A, Bailey K. Death, certification. StatPearls. Treasure Island (FL): StatPearls Publishing; 2018. Available at https:// www.ncbi.nlm.nih.gov/books/NBK526015/. Accessed 14 Dec 2018.

4. Ahn JS, Park YS, Kim J, Kim K. Mineralogical and geochemical characterization of arsenic in an abandoned mine tailings of Korea. Environ Geochem Health. 2005;27:147-57. https://doi. org/10.1007/s10653-005-0121-8.

5. Ailshire J, Karraker A, Clarke P. Neighbourhood social stressors, fine particulate matter air pollution, and cognitive function among older U.S. adults. Soc Sci Med. 2017;172:56-63. https://doi.org/ 10.1016/j.socscimed.2016 This paper shows how particles interact with social stressors to produce a poorer health outcome.

6. Alpers $\mathrm{CN}$. Arsenic and mercury contamination related to historical goldmining in the Sierra Nevada, California. Geochem: Explor, Environ, Anal. 2017;17:92-100. https://doi.org/10.1144/ geochem2016-018.

7. Antoszczyszyn T, Michalska A. The potential risk of environmental contamination by mercury contained in Polish coal mining waste. J Sustain Min. 2016;15:191-6. https://doi.org/10.1016/j. jsm.2017.04.002.

8. Arquette M, Cole M, Cook K, LaFrance PM, Ransom J, Sargent $\mathrm{E}$, et al. Holistic risk-based environmental decision making: a Native perspective. Environ Health Perspect. 2002;110:259-64.

9. Argyraki A. Garden soil and house dust as exposure media for lead uptake in the mining village of Stratoni, Greece. Env Geochem Heal. 2014;36:677-92. https://doi.org/10.1007/ s10653-013-9589-9.

10. Arnold C. A scourge returns. Black lung in Appalachia. Environ Health Perspect. 2016;124:A13-8.

11. Ascher M, Costa LG. Advances in Neurotoxicology; Environmental factors in neurodegenerative diseases. Cambridge: Academic Press; 2017. This book examines in detail environmental links to Parkinsonism, Alzheimer's disease and other chronic brain diseases.

12. ATSDR. Agency for toxic substances and disease registry. Toxic substances portal. Atlanta: ATSDR; 2011-2018. https://www. atsdr.cdc.gov/substances/indexAZ.asp\#A. Accessed 14 Jan 2019.

13. Baker D, Karalliede L, Murray V, Maynard R, Parkinson N, editors. Essentials of toxicology for health protection: a Handbook for Field Professionals, 2nd edn. Oxford: Open University Press; 2012.

14. Basu N, Clarke E, Green A, Calys-Tagoe B, Chan L, Dzodzomenyo $\mathrm{M}$, et al. Integrated assessment of artisanal and small-scale gold mining in Ghana - part 1: human health review. Int J Environ Res Public Health. 2015;12:5143-76. https://doi. org/10.3390/ijerph120505143.

15. Bayer O, Cámara R, Zeissig SR, Ressing M, Dietz A, Locati LD, et al. Occupation and cancer of the larynx: a systematic review and meta-analysis. Eur Arch Otorhinolaryngol. 2016;273:9-20. https://doi.org/10.1007/s00405-014-3321-y.

16. Balabanova B, Stafilov T, Sajn R, Tanaselia C. Long-term geochemical evolution of lithogenic versus anthropogenic distribution of macro and trace elements in household attic dust. Biljana Arch Environ Contam Toxicol. 2017;72:88-107.

17. Barbieri E, Fontúrbel FE, Herbas C, Barbieri FL, Gardon J. Indoor metallic pollution and children exposure in a mining city. Sci Total 
Environ. 2014;487:13-9. https://doi.org/10.1016/j.scitotenv.2014. 03.136 .

18. Beukes JP, du Preez SP, van Zyl PG, Paktunc D, Fabritius T, Paatalo M, et al. Review of Cr (VI) environmental practices in the chromite mining and smelting industry - relevance to development of the Ring of Fire Canada. J Clean Prod. 2017;165:874-89. https://doi.org/10.1016/j.jclepro.2017.07.176.

19. Bignasca A, Ianni C, Magi E, Rivaro P. Using proteolytic enzymes to assess metal bioaccessibility in marine sediments. Talanta. 2011;86:305-15. https://doi.org/10.1016/j.talanta.2011.09.018.

20. Boschetto P, Quintavalle S, Miotto D, Lo Cascio N, Zeni E, Mapp CE. Chronic obstructive pulmonary disease (COPD) and occupational exposures. J Occup Med Toxicol. 2006;1:1-11. https://doi. org/10.1186/1745-6673-1-11.

21. Boev B, Stafilov T, Bačeva K, Šorša A, Boev I. Influence of a nickel smelter plant on the mineralogical composition of attic dust in the Tikveš Valley, Republic of Macedonia. Environ Sci Pollut Res. 2013;20:3781-8.

22. Boisa N, Elom N, Dean JR, Deary M, Bird G, Entwistle JA. Development and application of an inhalation bioaccessibility method (IBM) for lead in the $\mathrm{PM}_{10}$ size fraction of soil. Environ Int. 2014;70:132-42. https://doi.org/10.1016/j.envint.2014.05. 021.

23. Breshears DD, Whicker JJ, Sáez AE, Field JP. Introduction to a special issue of aeolian research: airborne mineral dust contaminants: impacts on human health and the environment. Aeolian Res. 2014;14:1-2.

24. Cesaro A, Marra A, Kuchta K, Begiorno V, Van Hullebusch ED. WEEE management in a circular economy perspective: an overview. Global NEST J. 2018;20:743-50. https://doi.org/10.30955/ gnj.002623 Contains a useful inventory of metals and other contaminants.

25. Chen Y, Luo X, Zhao Z, Chen Q, Wu D, Sun X, et al. Summer winter differences of $\mathrm{PM}_{2.5}$ toxicity to human alveolar epithelial cells (A549) and the roles of transition metals. Ecotoxicol Environ Saf. 2018;165:505-9. https://doi.org/10.1016/j.ecoenv.2018.09. 034 .

26. Cipullo S, Prpich G, Campo P, Coulon F. Assessing bioavailability of complex chemical mixtures in contaminated soils: Progress made and research needs. Sci Total Environ. 2018;615:708-23. https://doi.org/10.1016/j.scitotenv.2017.09.321 This article offers valuable insights to move forward the integration of bioavailability into site-specific risk assessment.

27.• Clippinger AJ, Allen D, Jarabek AM, Corvaro M, Gaça M, Gehen $\mathrm{S}$, et al. Alternative approaches for acute inhalation toxicity testing to address global regulatory and non-regulatory data requirements: An international workshop report. Toxicol in Vitro. 2018;48:5370 This paper summarizes the presentations and discussions that took place at the Alternative Approaches for Identifying Acute Systemic Toxicity: moving from Research to Regulatory Testing workshop in 2015.

28. Clougherty JE, Rossi CA, Lawrence J, Long MS, Diaz EA, Lim $\mathrm{RH}$, et al. Chronic social stress and susceptibility to concentrated ambient fine particles in rats. Environ Health Perspect. 2010;118: 769-75. https://doi.org/10.1289/ehp.0901631.

29.• • Considine R, Tynan R, James C, Wiggers J, Lewin T, Inder K, et al. The contribution of individual, social and work characteristics to employee mental health in a coal mining industry population. PLoS One. 2017;12:e0168445. https://doi.org/10.1371/ journal.pone.0168445 This paper offers a guide into the effects of personal, occupational and social on health in Australian miners.

30. Crane RA, Sinnett DE, Cleall PJ, Sapsford DJ. Physicochemical composition of wastes and co-located environmental designations at legacy mine sites in the south west of England and Wales: implications for their resource potential. Resour Conserv Recycl. 2017;123:117-34.

31. Csavina J, Field J, Taylor MP, Gao S, Landazuri A, Betterton EA, et al. A review on the importance of metals and metalloids in atmospheric dust and aerosol from mining operations. Sci Total Environ. 2012;433:58-73.

32. • DeBord DG, Carreón T, Lentz TJ, Middendorf PJ, Hoover MD, Schulte PA. Use of the "Exposome" in the practice of epidemiology: a primer on -omic technologies. Am J Epidemiol. 2016;184: 302-14. https://doi.org/10.1093/aje/kwv325 A helpful introduction to the exposome, the strengths, pitfalls, issues of study design, and interlinks with epidemiology and omic disciplines.

33. Dellinger B, Pryor WA, Cueto R, Squadrito GL, Hegde V, Deutsch WA. Role of free radicals in the toxicity of airborne fine particulate matter. Chem Res Toxicol. 2001;14:1371-7. https://doi.org/10. 1021/tx010050x.

34. Dey T, Gogoi K, Unni BG, Kalita M, Bharadwaz M, Bhattacharjee $\mathrm{M}$, et al. Role of glutathione $\mathrm{S}$ transferase polymorphism in COPD with special reference to peoples living in the vicinity of the open cast coal mine of Assam. PLoS One. 2014;9: e96739. https://doi.org/10.1371/journal.pone.0096739.

35. Dignam T, Pomales A, Werner L, Newbern EC, Hodge J, Nielsen $\mathrm{J}$, et al. Assessment of child lead exposure in a Philadelphia community. J Public Health Manag Pract. 2019;25:53-61. https://doi. org/10.1097/PHH.0000000000000711.

36. Duffy CM, Swanson J, Northrop W, Nixon JP, Butterick TA. Microglial immune response to low concentrations of combustion-generated nanoparticles: an in vitro model of brain health. Nanomaterials. 2018;8:155. https://doi.org/10.3390/ nano8030155.

37. Engström KG, Angrén J, Björnstig U, Saveman BI. Mass casualty incidents in the underground mining industry: applying the Haddon matrix on an integrative literature review. Disaster Med Public Health Prep. 2018;12:138-46. https://doi.org/10.1017/ dmp.2017.31.

38. Ettler V, Polák L, Mihaljevi M, Ratié G, Garnier J, Quantin C. Oral bioaccessibility of inorganic contaminants in waste dusts generated by laterite Ni ore smelting. Env Geochem Heal. 2018;40:1699712. https://doi.org/10.1007/s10653-016-9875-4.

39. Fonseca-Nunes A, Jakszyn P, Agudo A. Iron and cancer risk - a systematic review and meta-analysis of the epidemiological evidence. Cancer Epidemiol Markers Prev. 2014;23:12-31. https:// doi.org/10.1158/1055-9965.EPI-13-0733 This study evaluated the cancer risk from increasing heme (organic) iron intake, and gives direction for further work on the protective nature of biomarkers for iron stores.

40.• Fernandez-Twinn DS, Constância M, Ozanne SE. Intergenerational epigenetic inheritance in models of developmental programming of adult disease. Semin Cell Dev Biol. 2015;43:85-95 This paper offers a clear introduction to epigenetics, including maternal and paternal contributions to transgenerational inheritance.

41.• GBD 2015 Chronic Respiratory Disease Collaborators. Global, regional, and national deaths, prevalence, disability-adjusted life years, and years lived with disability for chronic obstructive pulmonary disease and asthma, 1990-2015: a systematic analysis for the Global Burden of Disease Study 2015. Lancet Respir Med. 2017;5:691-706. https://doi.org/10.1016/S2213-2600(17)30293$\mathrm{X} A$ useful paper exploring the changing face of respiratory disease in time and space.

42.• Gordon S, Daneshian M, Bouwstra J, Caloni F, Constant S, Davies DE, et al. Non-animal models of epithelial barriers (skin, intestine and lung) in research, industrial applications and regulatory toxicology. ALTEX. 2015;32:327-78 The article presents the current state of the art of non-animal models of the skin, 
intestinal and pulmonary barriers and discusses future directions for the development of new models and the refinement of existing test methods.

43. Guney M, Chapuis RP, Zagury GJ. Lung bioaccessibility of contaminants in particulate matter of geological origin. Environ Sci Pollut Res. 2016;23:24422-34. https://doi.org/10.1007/s11356016-6623-3.

44. Guney M, Bourges CMJ, Chapuis RP, Zagury GJ. Lung bioaccessibility of as, $\mathrm{cu}, \mathrm{Fe}, \mathrm{Mn}, \mathrm{Ni}, \mathrm{Pb}$, and $\mathrm{Zn}$ in fine fraction $(<20 \mu \mathrm{m})$ from contaminated soils and mine tailings. Sci Total Environ. 2017;579:378-86. https://doi.org/10.1016/j.scitotenv.2016.11. 086.

45. Haas EJ, Mattson M. A qualitative comparison of susceptibility and behavior in recreational and occupational risk environments: implications for promoting health and safety. J Health Commun. 2016;21:705-13. https://doi.org/10.1080/10810730.2016. 1153765.

46. Han R, Ji X, Wu B, Wang T, Han L, Yang J, et al. Polymorphisms in interleukin 17A gene and coal workers' pneumoconiosis risk in a Chinese population. BMC Pulm Med. 2015;15:79. https://doi. org/10.1186/s12890-015-0076-1.

47. Harrington $\mathrm{AD}$, Tsirka SE, Schoonen MA. Inflammatory stress response in A549 cells as a result of exposure to coal: evidence for the role of pyrite in coal workers' pneumoconiosis pathogenesis. Chemosphere. 2013;93:1216-21.

48. Harrington AD, Smirnov A, Tsirka SE, Schoonen MA. Metalsulfide mineral ores, Fenton chemistry and disease - particle induced inflammatory stress response in lung cells. Int J Hyg Environ Health. 2015;218:19-27.

49. Hettiarachchi E, Paul S, Cadol D, Frey B, Rubasinghege G. Mineralogy controlled dissolution of uranium from airborne dust in simulated lung fluids (SLFs) and possible health implications. Environ Sci Technol Lett. 2019;in press. https://doi.org/10.1021/ acs.estlett.8b00557 Highlights the differential solubility of $\mathbf{U}$ mineral in different in vitro lung fluids and demonstrates the extracts accord with a predictive geochemical model.

50. Hitzman MW, Bookstrom AA, Slack JF, Zientek ML. Cobaltstyles of deposits and the search for primary deposits: US Geological Survey Open-File Report 2017-1155, 47p. 2017. https://doi.org/10.3133/ofr20171155.

51.• IARC. International Agency for Research on Cancer. IARC Monographs on the evaluation of carcinogenic risk to humans. 2018. https://monographs.iarc.fr/agents-classified-by-the-iarc/. Accessed 14 Jan 2019. This is the access page to every chemical that has been reviewed for carcinogenic potential by the IARC.

52. Jacobs M, Pienaar J. Stress, coping and safety compliance in a multinational gold mining company. Int J Occup Saf Ergon. 2017;23:152-61. https://doi.org/10.1080/10803548.2016. 1263476.

53. Jerrett M, Burnett R, Brook J, Kanaroglou P, Giovis C, Finkelstein $\mathrm{N}$, et al. Do socioeconomic characteristics modify the short term association between air pollution and mortality? Evidence from a zonal time series in Hamilton, Canada. J Epidemiol Community Health. 2004;58:31-40. https://doi.org/10.1136/jech.58.1.31.

54. Jiang XQ, Mei XD, Feng D. Air pollution and chronic airway diseases: what should people know and do? J Thorac Dis. 2016;8:E31-40.

55. Johann-Essex V, Keles C, Rezaee M, Scaggs-Witte M, Sarver E. Respirable coal mine dust characteristics in samples collected in central and northern Appalachia International. J Coal Geol. 2017;182:85-93.

56. Kasprzak KS, Waalkes MP. The role of calcium, magnesium, and zinc in carcinogenesis. Adv Exp Med Biol. 1986;206:497-515.

57. Kastury F, Smith E, Karna RR, Scheckel KG, Juhasz AL. Methodological factors influencing inhalation bioaccessibility of metal(loid)s in PM2.5 using simulated lung fluid. Environ Pollut. 2018;241:930-7. https://doi.org/10.1016/j.envpol.2018.05.094.

$58 . \bullet$ Kelly FJ, Fussell JC. Role of oxidative stress in cardiovascular disease outcomes following exposure to ambient air pollution. Free Radic Biol Med. 2017;110:345-67. https://doi.org/10.1016/ j.freeradbiomed.2017.06.019 This paper offers a detailed and comprehensive review of the evidence from animals, humans and in vitro studies across a range of cardiovascular diseases.

59. Kim CS, Tyler A, Goldstein D, Rytuba JJ. Windborne transport and surface enrichment of arsenic in semi-arid mining regions: examples from the Mojave Desert, California. Aeolian Res. 2014;14:85-96.

60. Kordas K, Ravenscroft J, Cao Y, McLean EV. Lead exposure in low and middle-income countries: perspectives and lessons on patterns, injustices, economics, and politics. Int J Environ Res Public Health. 2018;15:E2351 The article takes a multidisciplinary approach to examine the patterns of lead exposure in a range of countries.

61. Kristensen LJ, Taylor MP, Morrison AL. Lead and zinc dust depositions from ore trains characterised using lead isotopic compositions. Environ Sci: Processes Impacts. 2015;17:631-7.

62. Landrigan PJ, Fuller R, Acosta NJR, Adeyi O, Arnold R, Basu $\mathrm{NN}$, et al. The Lancet Commission on pollution and health. Lancet. 2018;391:462-512. https://doi.org/10.1016/S01406736(17)32345-0 A landmark paper that reviews of the way pollution affects health.

63. Latvala S, Hedberg J, Di Bucchianico S, Möller L, Odnevall Wallinder I, Elihn K, et al. Nickel release. ROS generation and toxicity of Ni and NiO micro- and nanoparticles PLoS ONE. 2016;11:e01e59684. https://doi.org/10.1371/journal.pone. 0159684.

64. Lewis J, Hoover J, MacKenzie D. Mining and environmental health disparities in Native American communities. Curr Environ Health Rep. 2017;4:130-41. https://doi.org/10.1007/ s40572-017-0140-5 This article provides a helpful review of different aspects of legacy of $U$ mining, deprivation, and social issues, with resulting health effects in Native American Indians due to proximity to mines, which is applicable in other communities.

65. Li Y, Demisie W, Zhang M. The function of digestive enzymes on $\mathrm{Cu}, \mathrm{Zn}$, and $\mathrm{Pb}$ release from soil in in vitro digestion tests. Environ Sci Pollut Res. 2013;20:4993-5002. https://doi.org/10.1007/ s11356-013-1472-9.

66. Liu Z, Ren Z, Zhang J, Chuang C-C, Kandaswamy E, Zhou T, et al. Role of ROS and nutritional antioxidants in human diseases. Front Physiol. 2018;9:477. https://doi.org/10.3389/fphys.2018. 00477.

67. Lu S, Hao X, Liu D, Wang Q, Zhang W, Liu P, et al. Mineralogical characterization of ambient fine/ultrafine particles emitted from Xuanwei C1 coal combustion. Atmos Res. 2016;169:17-23. https://doi.org/10.1016/j.atmosres.2015.09.020 This article describes with significant detail the mineralogy of ultrafine particles emitted by coal combustion and further considers the potential health risk associated with human exposure to nano-minerals in particulate matter.

68. Lynch SR. Iron physiology. In: Caballero B, editor. Encyclopedia of Food Sciences and Nutrition, 2nd edn. 2003. https://doi.org/10. 1016/B0-12-227055-X/00651-9.

69. Maier RM, Díaz-Barriga F, Field JA, Hopkins J, Klein B, Poulton MM. Socially responsible mining: the relationship between mining and poverty, human health and the environment. Rev Environ Health. 2014;29:83-9.

70. Mariotti A. The effects of chronic stress on health: new insights into the molecular mechanisms of brain-body communication. Future Sci OA. 2015;1:FSO23. https://doi.org/10.4155/fso.15.21. 
71. Marsit CJ. Influence of environmental exposure on human epigenetic regulation. J Exp Biol. 2015;218:71-9. https://doi.org/10. 1242/jeb.106971.

72. Martin R, Dowling K, Pearce D, Sillitoe J, Florentine S. Health effects associated with inhalation of airborne arsenic arising from mining operations. Geosciences. 2014;4:128-75. https://doi.org/ 10.3390/geosciences4030128.

73. Mason LH, Harp JP, Han DY. Pb neurotoxicity: neuropsychological effects of lead toxicity. Biomed Res Int. 2014;2014: ID840547. https://doi.org/10.1155/2014/840547.

74. Mehta N, Cocerva T, Cipullo S, Padoan E, Antonella G, Ajmonemarsan F, et al. Linking oral bioaccessibility and solid phase distribution of potentially toxic elements in extractive waste and soil from an abandoned mine site: case study in Campello Monti, NW Italy. Sci Total Environ. 2019;651:2799-810. https://doi.org/10. 1016/j.scitotenv.2018.10.115 This article presents a comprehensive, up-to-date discussion of how bioaccessibility and solid phase distribution of chemical elements, as well as the mineralogy of mine wastes, are key factors to the distribution, behaviour, and fate of potentially toxic elements in the environment.

75. Middleton DRS, Watts MJ, Beriro DJ, Hamilton EM, Leonardi GS, Fletcher T, et al. Arsenic in residential soil and household dust in Cornwall, south west England: potential human exposure and the influence of historical mining. Environ Sci Process Impacts. 2017;19:517-27. https://doi.org/10.1039/C6EM00690F.

76. Ngosa K, Naidoo RN. The risk of pulmonary tuberculosis in underground copper miners in Zambia exposed to respirable silica: a cross-sectional study. BMC Public Health. 2016;16:855. https:// doi.org/10.1186/s12889-016-3547-2.

77. Nemery B, Banza C, Nkulu L. Assessing exposure to metals using biomonitoring: achievements and challenges experienced through surveys in low- and middle-income countries. Toxicol Lett. 2018;298:13-8. https://doi.org/10.1016/j.toxlet.2018.06.004 The article highlights the role biomonitoring data can play for improved enforcement of legislation to protect workers and citizens against the hazards posed by the mining activities.

78. Nkosi V, Wichmann J, Voyi K. Chronic respiratory disease among the elderly in South Africa: any association with proximity to mine dumps? Environmental Health. 2015;14:33. https://doi.org/10. 1186/s12940-015-0018-7 A study looking at possible confounders and independent correlates or health issues.

79. NRC. National Research Council (US) Committee on Copper in Drinking Water. Copper in Drinking Water. Washington (DC): National Academies Press; 2000. 5, Health Effects of Excess Copper. https://wwwncbinlmnihgov/books/NBK225400/. Accessed 14 Jan 2019.

80. Oluwaseye FI, Iyakwari S, Idzi AA, Kehinde OH, Osu UH. Qualitative identification of copper bearing minerals using near infrared sensors. Physicochem Probl Miner Process. 2016;52(2): 620-33.

81. Oomen AG, Rompelberg CJM, Bruil MA, Dobbe CJG, Pereboom DPKH, Sips AJAM. Development of an in vitro digestion model for estimating the bioaccessibility of soil contaminants. Arch Environ Contam Toxicol. 2003;44:281-7. https://doi.org/10. 1007/s00244-002-1278-0.

82. Øvrevik J, Refsnes M, Låg M, Holme JA, Schwarze PE. Activation of proinflammatory responses in cells of the airway mucosa by particulate matter: oxidant- and non-oxidantmediated triggering mechanisms. Biomolecules. 2015;5:1399440. https://doi.org/10.3390/biom5031399.

83. Perez MF, Lehner B. Intergenerational and transgenerational epigenetic inheritance in animals. Nat Cell Biol. 2019. https://doi.org/ 10.1038/s41556-018-0242-9 Most up-to-date discussion on epigenetic inheritance available.
84.• PHE. Public Health England. Chemical hazards compendium. London: PHE; 2017. https://www.gov.uk/government/ collections/chemical-hazards-compendium. Accessed 14 January 2019. A good source of simple toxicology of important metals and other toxins.

85. Pino A, Chiarotti F, Calamandrei G, Gotti A, Karakitsios S, Handakas E, et al. Human biomonitoring data analysis for metals in an Italian adolescents cohort: An exposome approach. Environ Res. 2017;159:344-54. https://doi.org/10.1016/j.envres.2017.08. 012 A helpful, worked example of the exposome.

86. Predonzani A, Calì B, Agnellini AHR, Molon B. Spotlights on immunological effects of reactive nitrogen species: when inflammation says nitric oxide. World J Exp Med. 2015;5:64-76. https:// doi.org/10.5493/wjem.v5.i2.64.

87. Rytuba JJ. Mercury from mineral deposits and potential environmental impact. Environ Geol. 2003;43:326-38. https://doi.org/10. 1007/s00254-002-0629-5.

88. Schraufnagel DE, Balmes JR, Cowl CT, De Matteis S, Jung SH, Mortimer K, Perez-Padilla R, Rice MB, Riojas-Rodriguez H, Sood A, Thurston GD, To T, Vanker A, Wuebbles DJ. Air pollution and noncommunicable diseases: a review by the forum of international respiratory societies' environmental committee, Part 1: the damaging effects of air pollution. Chest. 2018a;S0012-3692(18)32723-5. https://doi.org/10.1016/j.chest. 2018.10.042. This paper and the next offer up-to-date review of how and what air pollution contributes to health.

89. Schraufnagel DE, Balmes JR, Cowl CT, De Matteis S, Jung SH, Mortimer K, Perez-Padilla R, Rice MB, Riojas-Rodriguez H, Sood A, Thurston GD, To T, Vanker A, Wuebbles DJ. Air pollution and noncommunicable diseases: a review by the forum of international respiratory societies' environmental committee, Part 2: air pollution and organ systems. Chest. 2018b;S00123692(18)32722-3. https://doi.org/10.1016/j.chest.2018.10.041. This paper and the previous one offer up-to-date review of how and what air pollution contributes to health.

90. Shi T, Schins RPF, Knaapen AM, Kuhlbusch T, Pitz M, Heinrich $\mathrm{J}$, et al. Hydroxyl radical generation by electron paramagnetic resonance as a new method to monitor ambient particulate matter composition. J Environ Monit. 2003;5:550-6. https://doi.org/10. 1039/b303928p.

91. Sinitkul R, Wongrathanandha C, Sirirattanapruk S, Plitponkarnpim A, Maude RJ, Marczylo EL. Children's environmental health in Thailand: past, present, and future. Ann Glob Health. 2018;84:306-29. https://doi.org/10.29024/aogh.2301.

92. Solís-López M, Durán-Moreno A, Rigas F, Morales AA, Navarrete M. Assessment of copper slag as a sustainable Fenton-type Photocatalyst for water disinfection. In: Satinder A, editor. Water Reclamation and Sustainability. USA: Elsevier; 2014.

93. Song X, Shao L, Zheng Q, Yang S. Characterization of crystalline secondary particles and elemental composition in PM10 of North China. Environ Earth Sci. 2015;2015(74):5717-27. https://doi. org/10.1007/s12665-015-4589-y.

94. De Souza E, Texeira R, Cardoso da Costa H, Oliveira F, Melo L, Faial K, et al. Assessment of risk to human health from simultaneous exposure to multiple contaminants in an artisanal gold mine in Serra Pelada, Pará, Brazil. Sci Total Environ. 2017;576:683-95. https://doi.org/10.1016/j.scitotenv.2016.10.133.

95. Stackelberg K, Guzy E, Chu T, Henn B. Exposure to mixtures of metals and neurodevelopmental outcomes: a multidisciplinary review using an adverse outcome pathway framework. Risk Anal. 2015;35:971-1016. https://doi.org/10.1111/risa.12425.

96.• Stewart AG, Hursthouse AS. Environment and human health. The challenge of uncertainty in risk assessment. Geosciences. 2018;8: 24. https://doi.org/10.3390/geosciences 8010024 A useful review of how public health professionals use and think about 
environmental determinants of disease. Well illustrated with figures and examples.

97. Tian S, Liang T, Li K, Wang L. Source and path identification of metals pollution in a mining area by PMF and rare earth element patterns in road dust. Sci Total Environ. 2018;633:958-66. https:// doi.org/10.1016/j.scitotenv.2018.03.227 This article stands for a comprehensive study comprising investigation on pollution levels, source apportionment, and pollution paths. The proposed methodology provides a practical tool for human exposure and health risk assessment studies.

98. United Nations Sustainable development goals: 17 goals to transform our world. 2016 . http://www.un.org/ sustainabledevelopment/development-agenda/. Accessed 14 Dec 2018.

99. US EPA. US Environmental Protection Agency. Guidance for evaluating the oral bioavailability of metals in soils for use in human health risk assessment. Office of solid waste and emergency response. OSWER 9285.7 80, Washington, DC; 2007. Available from https://nepis.epa.gov/. Accessed 14 Dec 2018.

100. Vignal C, Pichavant M, Alleman LY, Djouina M, Dingreville F, Perdrix E, et al. Effects of urban coarse particles inhalation on oxidative and inflammatory parameters in the mouse lung and colon. Part Fibre Toxicol. 2017;14:46. https://doi.org/10.1186/ s12989-017-0227-z.

101. Wang Y, Wang R, Fan L, Chen T, Bai Y, Yu Q, et al. Assessment of multiple exposure to chemical elements and health risks among residents near Huodehong lead-zinc mining area in Yunnan, Southwest China. Chemosphere. 2017;174:613-27. https://doi. org/10.1016/j.chemosphere.2017.01.055.

102. Weng S, Wang L, Rong Y, Liu Y, Wang X, Guan H, et al. Effects of the interactions between dust exposure and genetic polymorphisms in Nalp3, Caspase-1, and IL-1 $\beta$ on the risk of silicosis: a case-control study. PLoS One. 2015;10:e0140952. https://doi.org/ 10.1371/journal.pone.0140952.

103. Whitmee S, Haines A, Beyrer C, Boltz F, Capon AG, de Souza Dias BF, et al. Safeguarding human health in the Anthropocene epoch: report of The Rockefeller Foundation-Lancet Commission on planetary health. The Lancet. 2015;386:1973-2028.

104. Wilson ML, Renne E, Roncoli C, Agyei-Baffour P, Tenkorang EY. Integrated assessment of artisanal and small-scale gold mining in Ghana - part 3: social sciences and economics. Int J Environ Res Public Health. 2015;12:8133-56. https://doi.org/10.3390/ ijerph120708133.

105. WHO. World Health Organisation. Childhood Lead Poisoning. Switzerland 2010. http://www.who.int/ceh/publications/ leadguidance.pdf. Accessed 14 Dec 2018.

106. Wragg J, Cave M, Basta N, Brandon E, Casteel S, Denys S, et al. An inter-laboratory trial of the unified BARGE bioaccessibility method for arsenic, cadmium and lead in soil. Sci Total Environ. 2011;409: 4016-30. https://doi.org/10.1016/j.scitotenv.2011.05.019.

107. Wu K-G, Chang C-Y, Yen C-Y, Lai C-C. Associations between environmental heavy metal exposure and childhood asthma: a population-based study. J Microbiol Immunol Infect. 2018:in press. https://doi.org/10.1016/j.jmii.2018.08.001.

108. Xiao Z, Shao L, Zhang N, Wang J, Chuang H-C, Deng Z, et al. A toxicological study of inhalable particulates in an industrial region of Lanzhou City, northwestern China: results from plasmid scission assay. Aeolian Res. 2014;14:25-3.

109. Yang M, Xiao W, Yang X, Zhang P. Processing mineralogy study on lead and zinc oxide ore in Sichuan. Metals (Basel). 2016;6:93. https://doi.org/10.3390/met6040093.

110. Yin H, Tan N, Liu C, Wang J, Liang X, Qu M, et al. The associations of heavy metals with crystalline iron oxides in the polluted soils around the mining areas in Guangdong Province, China. Chemosphere. 2016;161:181-9. https://doi.org/10.1016/j. chemosphere.2016.07.018.

111. Yang K, Cattle SR. Bioaccessibility of lead in urban soil of Broken Hill, Australia: a study based on in vitro digestion and the IEUBK model. Sci Total Environ. 2015;538:922-33. https://doi.org/10. 1016/j.scitotenv.2015.08.084.

112. Yorio PL, Willmer DR, Haight JM. Interpreting MSHA citations through the lens of occupational health and safety management systems: investigating their impact on mine injuries and illnesses 2003-2010. Risk Anal. 2014;34:1538-53. https://doi.org/10.1111/ risa.12164.

113.• Zimmerman EB, Woolf SH, Haley A. Understanding the relationship between education and health: a review of the evidence and an examination of community perspectives. In: Kaplan R, Spittel M, David D, editors. Population Health: Behavioral and Social Science Insights. AHRQ Publication No. 15-0002. Rockville: Agency for Healthcare Research and Quality and Office of Behavioral and Social Sciences Research, National Institutes of Health; 2015. Review article, with some US focus, of the interaction between health and education.

114. Zhang J, Chen N, Fu G, Yan M, Kim YC. The safety attitudes of senior managers in the Chinese coal industry. Int J Environ Res Public Health. 2016;13:E1147. https://doi.org/10.3390/ ijerph13111147.

115. Zota AR, Riederer AM, Ettinger AS, Schaider LA, James P, Amarasiriwardena CJ, et al. Associations between metals in residential environmental media and exposure biomarkers over time in infants living near a mining-impacted site. J Expo Sci Env Epidemiol. 2016;26:510-9. https://doi.org/10.1038/jes.2015.76. Associations This article examines the associations between residential exposure and metal biomarkers in infants living near a mining-impacted site. The paper illustrates well how biomonitoring data can improve our understanding of exposure.

Publisher's Note Springer Nature remains neutral with regard to jurisdictional claims in published maps and institutional affiliations. 